\title{
The moss-back alga (Cladophorophyceae, Chlorophyta) on two species of freshwater turtles in the Kimberleys
}

\author{
Stephen Skinner ${ }^{1,2}$, Nancy FitzSimmons ${ }^{3}$ and \\ Timothy J. Entwisle ${ }^{1}$
}

\author{
${ }^{1}$ National Herbarium of New South Wales, Mrs Macquaries Road, Sydney NSW 2000 Australia \\ ${ }^{2}$ Southern ACT Catchment Group Inc., PO Box 2056, Kambah, ACT \\ Author for correspondence: waterwatch@sactcg.org \\ ${ }^{3}$ Institute for Applied Ecology, School of Resource, Environmental \& Heritage Sciences, University \\ of Canberra, Canberra, ACT 2601, Australia
}

\begin{abstract}
The range of the Australian freshwater alga Basicladia ramulosa Ducker is extended, both in its turtle hosts (Chelodina burrungandjii Thomson et al.; Emydura australis (Grey)) and in geography, to tropical northern Western Australia. Along with further morphological observations, sporangia are described for the first time in this taxon.
\end{abstract}

\section{Introduction}

Moss-back turtles (Fig. 1) have fascinated biologists for many years. While the carapace of a potentially amphibious turtle would be a challenging habitat for most aquatic organisms, it is perhaps surprising there are only a handful of attached algae reported from such sites. Edgren et al. (1953) detailed the range of host turtles then known in North America and the range of epizoic algae that included Rhizoclonium and Cladophora. Two further genera in the Cladophoraceae are the only macroalgae widely reported on turtle carapaces: the prostrate, spreading, endozoic (and possibly disease causing) Dermatophyton radicans Peter, and species of the heterotrichous genus Basicladia, responsible for the name 'moss-back'.

In the United States, Basicladia is considered a small epizoic genus on turtles and water snails, of three to four taxa (John 2003). Hamilton (1948) described sexual reproduction in North American species of Basicladia involving the fusion of biflagellate zooids as is commonly the case in the Cladophoraceae. From unialgal cultures and field experiments, Proctor (1958) provides a natural history of Basicladia in North America and contends that Basicladia will establish on various substrates if a source of inoculum, a mossback turtle, is present. Ernst and Norris (1978) added further to the understanding of B. crassa and its association with its host. B. chelonum is reported by Sherwood et al. (2003) to have been collected on rock in Ho'omaluhia Botanical Garden in Hawai'i but was brought in with imported freshwater turtles. 
In Australia, one species, Basicladia ramulosa Ducker, has been described and reported from Victoria and Queensland (Ducker 1958). The purposes of this note are to report its occurrence in northern Western Australia and inland New South Wales (a distribution pattern that almost certainly reflects lack of collecting rather than anything else), to expand the description given by Ducker (1958) to include reproductive structures and make further comments on both prostrate and erect anatomy, and report further host animals. Cladophora kosterae van den Hoek, a free living taxon morphologically close to Basicladia, has been reported from New South Wales (Skinner \& Entwisle 2004).

\section{Methods}

Collections were air dried or preserved in 70\% ethanol. Slides were stained with aniline blue and mounted in $40 \%$ Karo. Examination was done with a Leitz Laborlux $\mathrm{D}$ microscope and drawing tube; photomicrographs were taken with a Nikon Coolpix 4500 digital camera and enhanced using Adobe Photoshop. Collections and slides are maintained at NSW.

\section{Description}

Basicladia ramulosa Ducker, Hydrobiologia 10: 165 (1958)

Type: Victoria: Stratford, on Chelodina longicollis (Shaw), Ducker s.n., 11 Dec 1956 (MEL? - see notes below, K) n.v.

Thallus heterotrichous, consisting of a basal cushion (endozoic) and branched erect axes (epizoic) (Fig. 2), on the carapaces of freshwater turtles (Fig. 1). Basal system one or more layers of isodiametric (18-25 $\mu \mathrm{m}$ diam.) or irregular tubular $(11-18 \mu \mathrm{m}$ diam.) cells in and on the substrate (Fig. 3). Erect axes filamentous, uniseriate becoming secondarily bi/triseriate by adhesion of lower cells reinforced by downward growth of rhizoids (Figs 4, 5), becoming uniseriate again in upper axis, 34-61 $\mu \mathrm{m}$ diam., or, with buttressing by adhesion, to $91 \mu \mathrm{m}$ diam., terminal cell truncate, $14-25 \mu \mathrm{m}$ diam. Branching bifurcate or trifurcate, becoming pseudodichotomous, usually above the lower 3 or 4 cells; laterals with very acute adaxial angle, arising below the endwall (occasionally up to $1 / 3$ below endwall), $17-28 \mu \mathrm{m}$ diam.; terminal cells truncate 14-16 $\mu \mathrm{m}$ diam. (Fig. 6). Sporangia intercalary, thin-walled, 17-32 $\mu \mathrm{m}$ diam., 55-116 $(-145) \mu \mathrm{m}$ long, development acropetal until upper 10-20 cells of branch all sporangia; opening round, projecting, sub-terminally lateral, terminal in apical cell (Fig. 7). Zooids 24-64 per sporangium, $6 \times 6-9 \mu \mathrm{m}$, uniform, flagella 2 .

Distribution: Western Australia, Northern Territory, Queensland, New South Wales and Victoria and probably throughout the continental mainland, on at least Chelodina burrungandjii Thomson et al. (2000), C. longicollis (Shaw) and Emydura australis (Grey). The presence of C. burrungandjii in the Kimberley is confirmed in Georges et al. (2002). As the Chelodina host is often nomadic, although moss-backs are less frequently encountered than clean backs, it is probable that Basicladia ramulosa may be encountered throughout the ranges of the three reported hosts: tropical northwestern Australia for C. burrungandjii and Emydura australis, and eastern and south-eastern Australia, especially the Murray-Darling system for C. longicollis. Basicladia duckerae has yet to be collected from other hosts (turtles, water snails) or found free-living.

It is very likely that the Cladophora referred to in Strøm (1921) is Basicladia ramulosa also. The locality given for the list of desmids found with the Cladophora is the Daly 


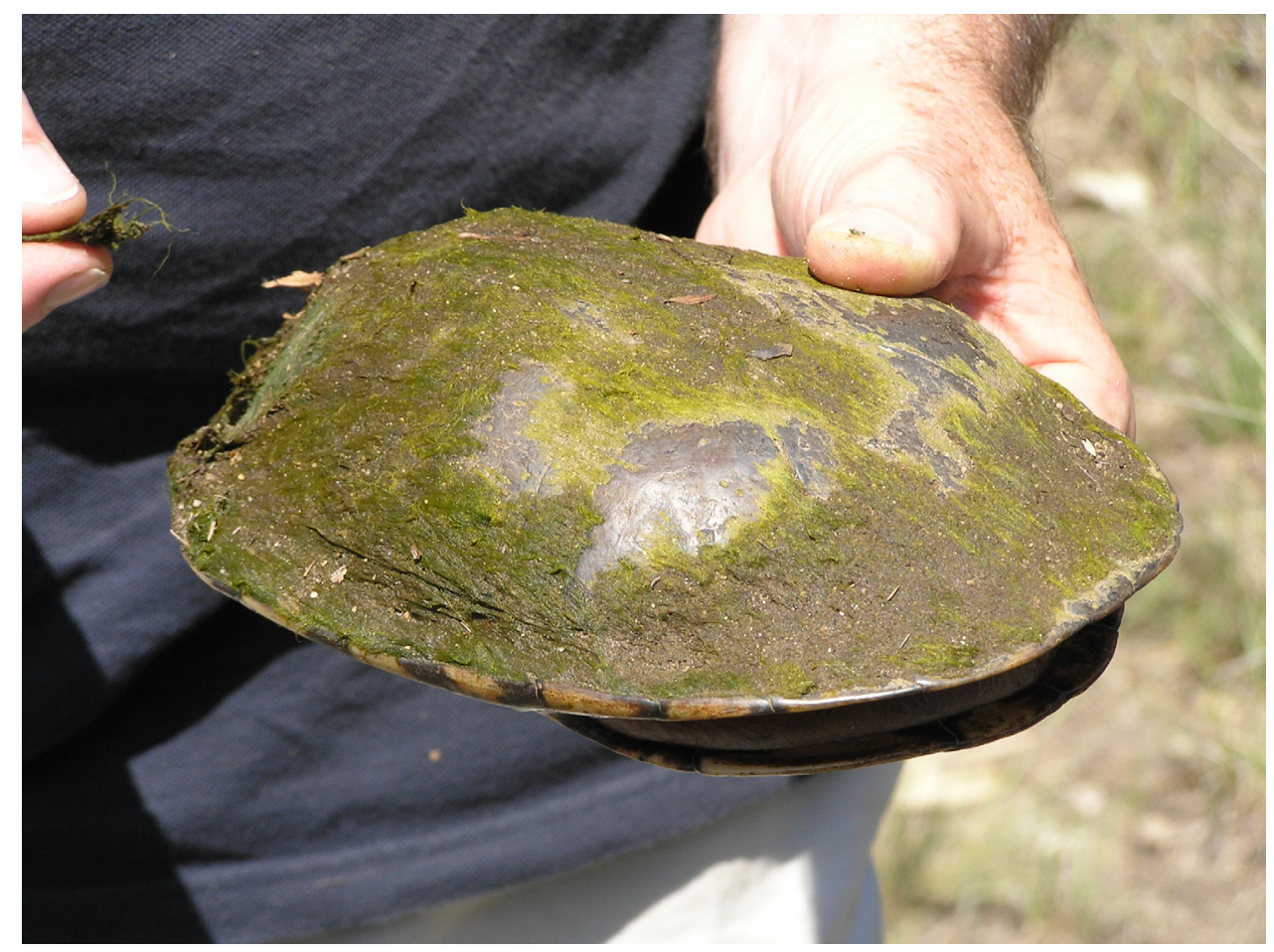

Fig. 1. Moss-back Chelodina longicollis, Copeton Dam Rd, N.S.W. (Photo G.M. Towler)

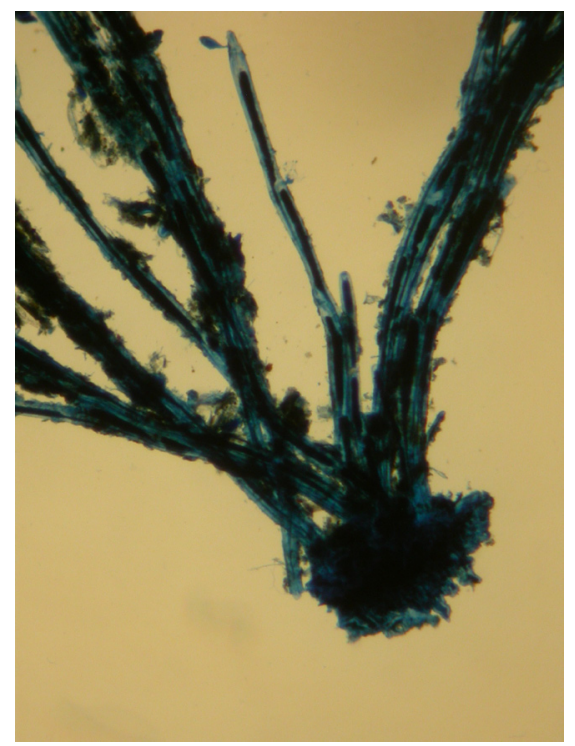

Fig. 2.

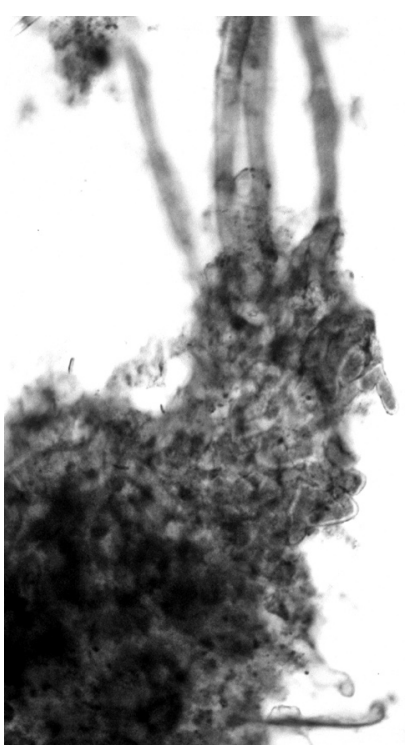

Fig. 3.

Fig. 2. Well developed multiseriate axes, FitzSimmons A5. Scale bar $=50 \mu \mathrm{m}$.

Fig. 3. Interlocking basal cells, Skinner 0781, McPherson \& Towler. Scale bar $=20 \mu \mathrm{m}$. 


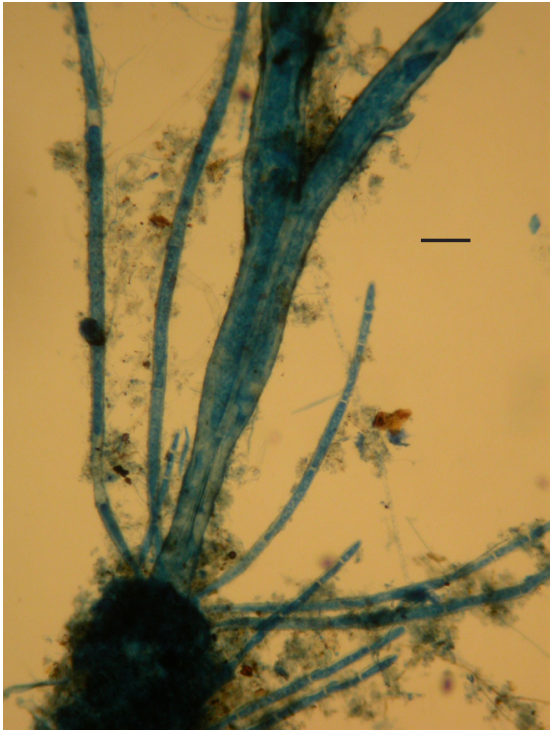

Fig. 4 .

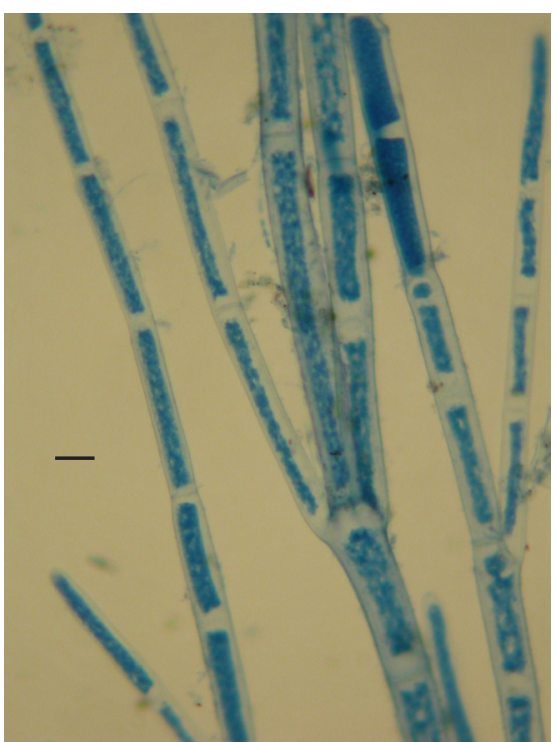

Fig. 6.

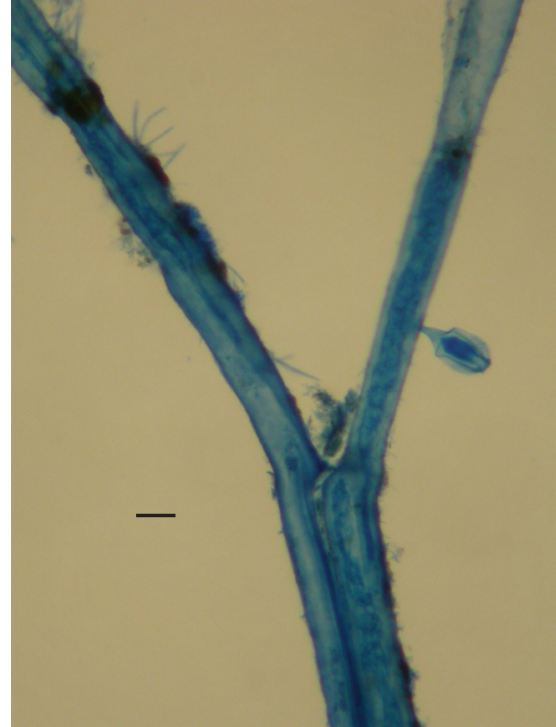

Fig. 5.

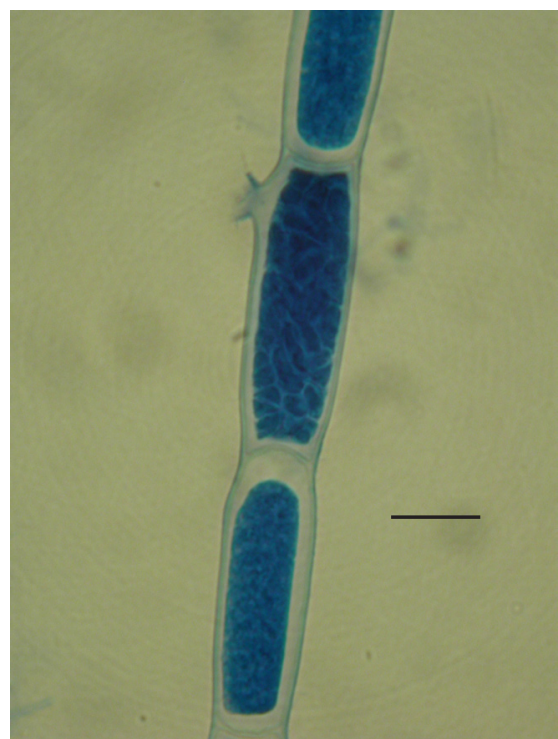

Fig. 7.

Fig. 4. Biseriate base of erect axis, Skinner 0781, McPherson \& Towler. Scale bar $=50 \mu \mathrm{m}$.

Fig. 5. Rhizoidal reinforcement of lower axis, FitzSimmons A5. Scale bar $=20 \mu \mathrm{m}$.

Fig. 6. Branching pattern showing narrow adaxial angle, Skinner 0781, McPherson \& Towler. Scale bar $=20 \mu \mathrm{m}$.

Fig. 7. Sporangium with open pore and zooids in formation, Skinner 0781, McPherson \& Towler. Scale bar $=20 \mu \mathrm{m}$. 
River, and the host turtle is called Chelodina oblonga Gray, identified by Dahl (most likely C. rugosa Ogilby as C. oblonga is confined to south-western Western Australia).

MEL have been unable to locate the type specimen; it isn't on Doris Sinkora's data base of algal specimens held in MEL and is possibly out on loan.

Specimens examined: Western Australia: Mornington Camp, Annie Creek, Fitzroy R. (17 $30^{\prime}$ 29"S, $126^{\circ} 06^{\prime} 42^{\prime \prime E}$ ), on Chelodina burrungandjii; ibid, FitzSimmons A1, Jun 2004; ibid, FitzSimmons Cb06, 8 Jun 2006 (NSW); ibid, on Emydura australis, FitzSimmons 3, Jun 2005 (NSW);

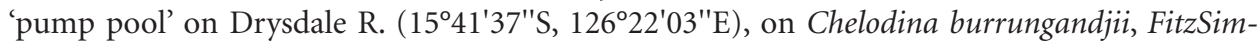
mons A3; ibid, on Emydura australis, FitzSimmons A4, Jun 2004 (NSW); Miners Pool, Drysdale R. (15²40'55"S, $\left.126^{\circ} 24^{\prime} 12^{\prime \prime} \mathrm{E}\right)$, on Chelodina burrungandjii, FitzSimmons A5/6, Jun 2004 (NSW);

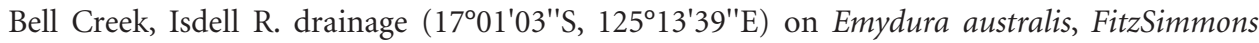
2, Jun 2005 (NSW). New South Wales: floodway, Copeton Dam Rd, near Staggy Ck turnoff (29 50'08'S, 15053'31"E), on back of snake-necked turtle, Chelodina longicollis, Skinner 0781, McPherson \& Towler, Oct 2004 (NSW).

Other Australian records: Victoria: Stratford, on C. longicollis, S.C. Ducker, Dec 1956 (MEL?; K) (Ducker 1958). Queensland: Aspley, near Brisbane, J.E. Coaldrake, Apr. 1957 (MEL?) (Ducker 1958). Northern Territory: lagoons near Daly River, Knut Dahl, 1894 (UPS?) (Strøm 1921)

\section{Morphological Observations}

Prostrate system: from the sections she made of the prostrate system on and in the stratum corneum, Ducker (1958, p 162) concluded that the cells 'in general are round or somewhat angular, ranging from $15 \mu \mathrm{m}$ to $30 \mu \mathrm{m}$ in diameter'. The prostrate system in our material appeared filamentous but compacted with multilobed cells interlocking to form the basal cushion from which arose the erect axes (Fig. 3 - it is often difficult to obtain undamaged basal material, with sufficient clearance of cuticle and detritus for good lighting for microphotography and this was the best material available).

Erect axes: Ducker's (1958) descriptions and illustrations of basal cells of recently produced erect axes are verified by our observations. Older, more established bases of erect axes however appear to adhere, and so become multiseriate, becoming buttressed by the extension downwards of close fitting rhizoid-like growths from the cell or cells above (Figs 4,5). Such multiseriate axes may involve the lower three or four cells in an axis. A similar, but much shorter, downward growth of cells at branches could be observed throughout the axis, except in the fresh growth towards the ends of axes. In some cases fusion between the walls of axial and lateral cells was observed, especially in older parts of the thallus (Figs 2,4). While speculative, it is inviting to think that both the rhizoidal buttressing and the adhesions are responses to frequent changes in temperature and wetting associated with the turtles' lifestyle.

Reproductive structures: Ducker (1958) does not mention reproductive structures. While no zooids were observed in Western Australian material (the material arrived either dry or already preserved) some upper cells in young filaments were modified as sporangia, thin walled, L/D 1.5- 4, with a subterminal funnel-like pore. The New South Wales material had well developed moniliform sporangial series, with mature, discharging and empty sporangia.

Hoffmann and Tilden (1930) described the sporangia in B. crassa as short and almost as broad as long, with the pore in various positions. This form of sporangium differs from that described by Hoffmann and Tilden (1930) for B. chelonum, and by van den 
Hoek (1963) for C. kosterae and C. okamurai (Ueda) van den Hoek, all of which have (sometimes multiple) lateral pores close to the middle of the sporangium. Hamilton (1948) found that the North American species released biflagellated gametes from sporangia in moniliform series, sometimes up to 18 in $B$. crassa, opening through a lateral pore. His illustration (Plate 1, figs 3-5) indicates that the pore in B. chelonum may be displaced towards the top of the sporangium rather than precisely central. The position and number of pores in sporangia needs further examination before it can be used reliably to discriminate between taxa.

\section{Acknowledgments}

This paper is dedicated to the memory of Sophie Ducker (1909-2004) who did so much for the study of algae, marine and freshwater, in Australia. Dr FitzSimmons was supported by Earthwatch Institute and the Hermon Slade Foundation. The turtle apprehended near Copeton Dam was encountered during a survey of freshwater algae in the Border Rivers and Gwydir Catchment Management Area, supported by a Hermon Slade Foundation grant. Thanks to Gillian Towler and Hannah McPherson for the 'moss-back' photograph, and helping with collection, Julia Sideris for much work on the photomicrographs and Peter G Wilson for advice on taxonomic matters.

\section{References}

Ducker SC (1958) A new species of Basicladia on Australian freshwater turtles. Hydrobiologia 10: 157-174.

Edgren RA, Edgren MK \& Tiffany LH (1953) Some North American turtles and their epizoophytic algae. Ecology 34: 733-740.

Ernst CH \& Norris JN (1978) Observations on the algal genus Basicladia and the Red-bellied Turtle, Chrysemys rubriventris. Estuaries 1: 54-57.

Georges A, Adams M \& McCord W (2002) Electrophoretic delineation of species boundaries within the genus Chelodina (Testudines: Chelidae) of Australia, New Guinea and Indonesia. Zoological Journal of the Linnaean Society 134: 401-421.

Hamilton JM (1948) Sexual reproduction in the genus Basicladia (Thallophyta, Chlorophyceae). Transactions of the American Microscopical Society 67: 201-205.

Hoek C van den (1963) Revision of the European species of Cladophora. (E.J. Brill: Leiden)

Hoffman WE \& Tilden JE (1930) Basicladia, a new genus of Cladophoraceae. Botanical Gazette 89: 374-384.

John DM (2003) Filamentous and Plantlike Green Algae. Pp. 311-352 in Wehr JD \& Sheath RG Freshwater Algae of North America. (Academic Press, San Diego)

Proctor V (1958) The growth of Basicladia on turtles. Ecology 39: 634-645.

Sherwood AR, Kido MH \& Morden CW (2003) New records of freshwater macroalgae from the Hawaiian Islands. I Chlorophyta. Pp 1-3 in Evenhuis NL \& Eldridge LG (eds) Records of the Hawaii Biological Survey for 2001-2002. Bishop Museum Occasional Papers, No. 74.

Skinner S \& Entwisle TJ (2004) Non-marine algae of Australia: 6. Cladophoraceae (Chlorophyta) Telopea 10: 731-748.

Strøm KM (1921) Algological notes. 1 Some desmids from North Australia. Nyt Magazin for Naturvidenskaberne 59: 1-14.

Thomson S, Kennett R \& Georges A (2000) A new species of long-necked turtle (Testudines: Chelidae) from the Arnhem Land Plateau, Northern Territory, Australia. Chelonian Conservation and Biology 3: 675-685. 